\title{
TOURISM, BASIC EDUCATION AND UNIVERSITY EXTENSION: A REPORT OF EXPERIENCE
}

\author{
Jislane Oliveira de Jesus a \\ Estefan Araujo dos Santos $b$ \\ Rosana Eduardo da Silva Leal c
}

\begin{abstract}
Extension actions and projects can help maintain the relationship between the university and society, in order to meet the needs of the external community, maintaining connections with social demands, public policies and diverse social movements in order to reduce inequalities and promote social inclusion. The project UFS de Braços Abertos, which is linked to the course in Tourism, is one such project. It offers guided tours for visiting elementary and high school students to the university campus, in order to present the university, its courses, the services offered, and the research and extension projects developed, creating a closer relationship between higher education and basic education. Based on this premise, this work analyzes the relationship between tourism, university extension and basic education, through the guided tours conducted as part of the UFS de Braços Abertos project, focusing on specifically on the participation of the Executive Secretarial course. In terms of approach to the problem, this study used qualitative research. The methodological procedures adopted were bibliographic research, and interviews with the head of the Executive Secretarial department and students of the course. We also sought to identify the perceptions of lecturers of the Executive Secretarial course in relation to the importance of the project, and the visits by school students to the University. The project helps to demystify the widely held perception, among students in basic education, that attending a federal university is a distant reality. The school students often arrive with this view, but after the visit, they are able to understand more how this universe works, and can dream of applying for place at university when they leave school. The report of experience presented clearly shows the important role of the UFS de Braços Abertos project, not only for the school students who may enter the university in the future, but also for students of the Tourism and Executive Secretarial courses, as it gives them an opportunity to promote and publicize the courses, stimulating the curiosity of the visiting students and showing them more about the respective professions, which can help them make future career choices.
\end{abstract}

KEYWORDS: Tourism; Extension; Basic Education; UFS. 


\section{INTRODUCTION}

The university has established reciprocal relationships with society since its beginnings, absorbing changes to adapt to the context of each new era and demand. According to Oliveira; Melo (2013, p.02), in the Middle Ages, the university developed its role through teaching, but with the institution of modern science, a new social function was established; research. At the end of the 19th century, the contributions of the university were extended to society through extension activities. However, at that time, the interests of specific groups were taken into account, but not those of society as a whole. The authors also point out that, "the Brazilian context was no different, as university institutions in Brazil were invariably permeated by the interests of privileged groups economically, culturally and politically" (OLIVEIRA; MELO, 2013, p.02).

In a new scenario, the university started to meet the interests of several groups with different expectations, such as: the State, the market and society, each with their respective demands.

"The functionalist conception via other purposes for the university and another way of linking it to society and government. The university' mission was focused on social needs, with the function of serving the nation and the purpose of being of collective, sociopolitical and socioeconomic utility. (PEREIRA, 2009, p. 32)"

For a long time, no notable connections have been established between the university and basic education. But with the expansion of primary education, this scenario has changed, and the demand for teacher training has grown significantly. Oliveira; Melo $(2013$, p. 05$)$ point out that: "It can be inferred that the Brazilian university did not deal with basic education until very recently, a situation that seems to have changed since the 1980s. The university has always been connected to projects of society or the country. Basic education was guaranteed as a right of every citizen and a duty of the State through qualified offers only with the 1988 Federal Constitution (CF) and LDBEN/1996. So it is in this context that the university begins to turn to basic education, since it is at this moment that it becomes the obligation of the State." Through its extension activities, the university maintains relationships with society in order to meet community needs and create relationships with public policies and different social groups, with the aim of reducing inequalities and promoting social inclusion. One such project is UFS de Braços Abertos', which aims to stimulate interest among students of public and private schools, in applying for courses at the Federal University of Sergipe (UFS). It does this by offering guided tours of the campus. The purpose of these visits is to show the students the facilities and present the courses in a dynamic way, while giving them an idea of the daily life of the university. The project started in the Tourism Degree course at the UFS, and is supported by monitor grants. Volunteer students of Tourism help plan, organize and carry out the guided visits, giving them the opportunity to put into practice the theoretical contents of various disciplines in the course, while the guided tours give them opportunities to gain practical experience. Thus, through the presentation of a report of experience, this study analyses the relationship between tourism, university extension and basic education, through the guided tours of the UFS de Braços Abertos project, focusing specifically on the participation of the Executive Secretarial course. Its specific objectives are: to understand the role of the UFS de Braços Abertos project and how it articulates with schools; to analyze the importance of the guided visits carried out with the participation of the Executive Secretarial course, and to investigate the methodologies used by the respective course to dialogue with the students in Basic Education.

${ }^{1}$ Scientific production linked to the Anthropology and Tourism Research Group - ANTUR/UFS/CNPQ and the extension project "UFS de Braços Abertos", which has the institutional support of the Pro-Rectorate of Undergraduate Studies of the Federal University of Sergipe - PROGRAD/UFS and is sponsored by monitoring grants, through the Joint Call No. 02/2019/PROGRAD/PROEST.

${ }^{2}$ To preserve the identification and authenticity of the projects, we have used the titles in Portuguese. The translation into English is: UFS OPEN ARMS PROJECT 


\section{Problem AND ReLeVANCE}

The Executive Secretarial Bachelor's degree course is offered by the Federal University of Sergipe, São Cristóvão Campus. Classes take place in the evenings, and intake is annual, with fifty available places each year. The secretarial profession is one with good job prospects, as this professional acts in the role of management advisory at several levels and in all types of organization, contributing to the efficiency of organizational processes (PROGRAD, 2019).

The course is part of the Applied Social Sciences. Although the course itself is not well-known in society, the importance of the secretarial profession, and its value in the labor market, are well-recognized. This course was picked as subject of this report through a draw among the monitors, which included other degrees that have already participated in the actions of the project, so that each member could leave their scientific contribution through reports like this one.

Based on these guidelines, we ask the following questions: How does the UFS de Braços Abertos Project promote dialogue between the university and basic education? and How can the participation of the Executive Secretarial course in the UFS de Braços Abertos Project contribute to the visibility of the course? Through this report of experience, we will analyze how the Executive Secretarial course participated in two actions of the project, and the reports of the speakers involved, as well as seeking to understand the importance of the project for giving visibility to the course.

\section{METHODOLOGY}

The problem is addressed through qualitative research, which enables the study of various phenomena and their social relations in the most different environments: "The experiences of individuals and their perceptions are useful and important aspects for the research. The reality is built together between researcher and subject through individual experiences" (PATIAS; HOHENDORFF, 2019, p. 02)."

For the elaboration of the theoretical reflections, a bibliographical survey was carried out. "In general terms, bibliographic research is an overview of the main sci- entific works already carried out on the chosen topic, which are important because they are able to provide current and relevant data" (BONI, QUARESMA, 2005, p. 71). The theoretical framework was used to search for and select texts with the same line of thought, which were compatible with the theme of this research, and which guided the statements and explanations developed. According to Galvão (2010, p.377), "to carry out a bibliographic survey is to intellectually enhance oneself with collective knowledge in order to go beyond".

This study also used descriptive research, the purpose of which is to describe the a particular reality in an impartial way, without the interference of the researchers. For a more detailed study, the content obtained through the Mapping of Courses at the Federal University of Sergipe, for the Executive Secretarial course, was used to guide the relevant information, which was fundamental during the presentations of the referred course. This Mapping was a result of a collective work of the UFS de Braços Abertos project's team of monitors, and included information on the physical structure, research and extension projects, teachers, and other administrative information about the courses.

Gil (2002, p.42) states that "the primary goal of descriptive research is to describe the characteristics of a given population or phenomenon, or the establishment of relations between variables". According to Souza and Diesel $(2008$, p. 58) "the main contribution of this type of research is to present a faithful and accurate description of a specific object or phenomenon". Descriptive research is not only scientific; it also value to market research, in order to generate information that helps in decision making.

Finally, interviews were conducted to gather more information about the object of study. These were applied to the student and teacher who presented and represented the Executive Secretarial course in the actions of the UFS de Braços Abertos project. These individuals were selected for the interviewees because they were the ones who presented the course to the school students, and therefore had direct contact with them. The purpose of the interviews was to find out what the experience was like, and its 
importance in building relationships between basic education and the university. In regard to the interview technique, Duarte $(2005$, p.62) explains that "it has become a classic technique of obtaining information in the social sciences, with wide adoption in areas such as sociology, communication, anthropology, administration, education and psychology.

The interview is a technique that is part of the data collection, enabling the researcher to have more contact with the interviewee and find out their views on a particular subject. The interview may be structured, with pre-defined questions, or semi-structured, giving the researcher more freedom. "The interview is one of the instruments that allows social workers to become aware of the relationships of interactions that are established between reality and the subjects, whether individual or collective" (LEWGOY; SILVEIRA, 2007, p. 235).

\section{RESULTS}

Extension activities developed in universities, such as the UFS de Braços Abertos project, allow the local community to draw closer to the academic environment, becoming a tool for educational social inclusion. This project is directed at elementary and high schools that visit the São Cristóvão campus of the Federal University of Sergipe, and is connected to the Department of Tourism, in partnership with the Pro-Rectorate of Undergraduate Studies - PROGRAD.

During the guided tours, spaces are presented such as the Central Library (BICEN), the Rector's Office, and the various services offered in this location, such as the University Restaurant (RESUN) and the space known as the Praça de Democracia. The three courses preferred by the visiting institution are also presented. Schools can contact the project via e-mail (escolasnaufs@gmail.com) or through Instagram (@ufsdebracosaberto).

Once the school has contacted the project, the monitors draw up an itinerary, which involves: choosing the schedule for each presentation or visit to the laboratories, among other spaces of the university; scheduling with the selected courses and the auditorium to be used; and drawing up a list of students and teachers who will visit the university and the monitors who will also take part in the activity. Two days before the visit, the monitors contact the school and the scheduled spaces, to confirm the visit, so that everything goes smoothly and according to plan. Through this experience, the monitors are able to practice hospitality, planning, scripting, marketing and organization of events pertinent to the formation of the professional in Tourism, putting into practice what they have learned in the classroom.

The guided tour presents the university, the courses and services offered, and its research and extension projects, promoting a connection between higher education and basic education. The project also seeks to demonstrate that enrolling in a federal public university can become a reality for students from both private and public schools, whether they live in the capital or in the more rural parts of the state. Often, during the actions, the team will hears comments like: "I never imagined myself going to a Federal University". So the school students start their visit with one perspective and end up gaining a different one, with a desire to enter university later on.

The project has partnerships with various university courses, and in each visit, three degree courses are selected, depending on the preference of the school. The selected courses might include: Executive Secretarial, Medical Physics, Zootechny, Biology, Civil Engineering, Physical Education, History, Geography, Libras, Geology, among others that have shown an interest in and a commitment to participating in the project.

The pilot project has been running as an extension action since 2013, at the São Cristóvão Campus of the Federal University of Sergipe. A team was also formed at the Itabaiana Campus, which has been receiving groups of visitors since the end of 2019.

The degree courses in Agrarian and Biological Sciences emphasize, with more theoretical and practical bases, the importance of environmental sustainability and how it should be part of our daily lives. Economic sustainability is addressed through lectures of courses such as: Economics, Accounting, Actuarial Science and Administration.

One of the difficulties of the school visits is the dependence on transportation to bring the students to the university. The majority of requests for appoint- 
ments are answered, but some institutions have stopped participating in the project due to a lack of transport, often canceling just one day before the scheduled date. But it is seen that several students who have participated in the project have now enrolled in courses at the university. Many report that the visit helped in their choice of the course, and they feel fulfilled with the new achievement, partly attributing this to their visit to the university before deciding what career to pursue.

The Executive Secretarial course has participated in two of the visits linked to the UFS de Braços Abertos. The first took place on April 30, 2009, during the second day of the induction period for freshmen (Acalore-se), which received students from the 1 st and 2 nd grades of the Armindo Guaraná State College of São Cristóvão/SE. The students from the respective course took part in a round table with students of other degrees, to explain what it is, what it does, and what the job market of the course is like. The second visit took place on October 16, 2019, with the visit by students from Colégio Eduardo Marques in Simão Dias/SE.

Through these two actions, we sought to identify the perceptions of the lecturers of the Executive Secretarial course about the importance the visits by other educational institutions to the University. Interviews were conducted with Professor Dr. Sueli Maria da Silva Pereira, Head of Department of the respective course, who also contributed during the lecture, and the student José Bruno Barros dos Santos, who is currently taking the 5 th period of the selected course.

When asked about the importance of the participation of the course in UFS de Braços Abertos project, the student José Bruno explained that: "The project itself has contributed to broadening the vision of the University among students in basic education, strengthening contact between both sides and presenting the higher level courses of the Center for Applied Social Sciences CCSA. We were able to give greater visibility to the course and the profession, which students often don't know about, contributing to the possible construction of a career plan for the target audience, and breaking with the paradigms that the course is for women only. "3

Prof. Dr. Sueli added that: "Being able to welcome stu- dents from public schools was very pleasant. It was an opportunity to generate good expectations among the students that going to university is an achievable goal for them, and that the university is a space that is available at any time." 4

Regarding the contribution of the project to the visibility of the Executive Secretarial degree, Prof. Dr. Sueli emphasized that "It is an action that certainly allows the visibility of the course because it is possible to talk about the course and dialogue with the students about the course. José Bruno added: "So we had an opportunity to present the course and talk a little bit about the profession of Executive Secretary and its various options for action. Through this, we aroused the students' curiosity by increasing their affinity for the course and passing on knowledge in a voluntary way." ${ }^{5}$ Concerning the methodology used during the actions, a presentation was given in dialogue with the students, with reports from the student of the Executive Secretarial course. The professor's participation included a presentation of the course and the job market, and an informative brochure was handed out. Banners were also displayed, showing some of the research and extension projects carried out by students and professors. At the end of the lecture, there was a prize draw for items showing the course logo, to promote greater interaction with the students.

In her report of her experience with the UFS de Braços Abertos project, and its importance to the academic community and society, Prof. Dr. Sueli said: "I am a fan of the project. It was wonderful to participate in the project with the coordinator and the students. For the professors and students of UFS we put into practice our role of developing extension actions and being able to serve society."

\footnotetext{
${ }^{3}$ Interview held on June 25, 2020.

${ }^{4}$ Interview held on June 24, 2020.

${ }^{5}$ Interview held on June 25, 2020

${ }^{6}$ Interview held on June 24, 2020
} 
The student José Bruno explained that: "The participation in the project was extremely gratifying. This strengthening between academia and society is very important because it shows what is going on beyond our four walls, and brings society closer to the field of education and science, which are produced in order to give back to society. Not to mention that it was incredible to have a conversation with the school students and see how interested they are in knowing how a University works and all the centers and departments." ${ }^{7}$ As reported in the interviews, the actions of UFS de Braços Abertos enabled dialogue between the academic community and the school students. The project promotes the Federal University of Sergipe while encouraging students to enter the university. The courses that take part in the visits have the opportunity to present themselves, aiming to win a new target audience, and it is a chance to demystify various aspects surrounding certain degree courses, as well as helping students to decide on a future career path, and instilling in them a desire to be part of this universe.

\section{Practical Implications AND CON- CLUSIONS}

Through the actions of the UFS de Braços Abertos project, we can analyze several aspects, such as: the experience and perception of the students who attended the visit; the point of view of the school teachers about the importance of strengthening ties between basic education with the university; how the courses can contribute to their visibility and their contributions to society, which serve for a deeper study, allowing closer links between the local community with the academic environment and becoming a tool for educational social inclusion.

The actions developed are innovative because of the didactics used, differing from many university institutions. The actions are not limited to lectures but allow greater proximity with the campus and the daily life of the university, through visits to the laboratories and museums, interactive presentations for the students, and contact with the main services offered at the university. This allows the visitors to broaden their perception of what day-to-day life in the university is like.
The project demystifies the concept, among many students in basic education, that going to a federal university is a distant reality for them. These students often arrive with this perspective, but after the visit, they are able to see how this universe operates, and can start to dream of applying for a place at the university when they leave school.

Through the report of experience presented, the UFS de Braços Abertos project has an important role, not only for the school students who visit, but also for students of the Tourism and Executive Secretarial degrees, among others, who have the opportunity to publicize and promote the courses in a way that will stimulate the visitors' curiosity and promote the respective professions, helping the school students to decide on their future careers.

\section{REFERENCES}

BONI, V; QUARESMA, S. J. Aprendendo a entrevistar: como fazer entrevista em ciências sociais. Em Tese, Florianópolis, v.2, p. 71, 2005

DUARTE, J. Métodos e técnicas de pesquisa em comunicação. São Paulo: Atlas 1, 2005.

GALVÃO, M. C. B. Fundamentos de epidemiologia. 2. ed. 2010.

O levantamento bibliográfico e a pesquisa científica. In: FRANCO. L. J.; PASSOS, A. D. C. (Orgs). Fundamentos de epidemiologia. 2 ed. São Paulo: Manole, 2011.

GIL, A. Como classificar as pesquisas? In: Como elaborar projetos de pesquisa. São Paulo: Atlas, 2002.

LEWGOY, A. M. B; SIVEIRA, E. M. C. A entrevistas nos processos de trabalho do assistente social. Porto Alegre, 2007.

OLIVEIRA, N. F. C; MELO, S. D. G. Extensão universitária e educação básica. 36a Reunião Nacional da ANPEd - 29 de setembro a 02 de outubro de 2013, Goiânia-GO.

PATIAS, N. D; HOHENDORFF, J. V. Critérios de qualidade para artigos de pesquisa qualitativa. Psicologia em Estudo. vol. 24, Maringá, 2019.

PEREIRA, E. M. de A. A universidade da modernidade nos tempos atuais. Avaliação, Campinas; Sorocaba, SP, v.14, n.1, p.2952, mar.2009.

PROGRAD. Catálogo cursos de graduação. 3. ed. São Cristóvão: Editora UFS, 2019.

SOUZA, R. S; DIESEL, V. Metodologia da pesquisa. Brasil, 2008.

${ }^{7}$ Interview held on June 25, 2020. 